\title{
A New Schiff Base Derivatives Designed to Bind Metal Ion (Cu, Co): Thermodynamics and Biological Activity Studies
}

\author{
Hanaa Hameed Haddad \\ Chemistry Department, College of Scienc, Basrah University, Basrah, Iraq \\ Email: hanaahadadd@yahoo.com
}

Received 26 March 2016; accepted 10 May 2016; published 13 May 2016

Copyright (C) 2016 by author and Scientific Research Publishing Inc.

This work is licensed under the Creative Commons Attribution International License (CC BY). http://creativecommons.org/licenses/by/4.0/

(c) (i) Open Access

\begin{abstract}
Schiff base synthesis is usually acid catalyzed and it usually requires refluxing the mixture of aldehydes and amine in ethanolic solution. Synthesis and characterization of Schiff base ligands derived from substituted amine and salicylaldehyde and their complexes $\left(\mathrm{Cu}^{2+}, \mathrm{Co}^{2+}\right)$ are reported. The ligands and ligand-complexes were characterized by melting point, FTIR, CHN-elemental analysis and UV-Visible analysis. The UV-Visible and elemental analysis of complexes established (1:2) mole ratio (M:L). The stability constant and thermodynamic parameters $(K, \Delta G, \Delta H, \Delta S)$ were determined at different temperature $(30-40)^{\circ} \mathrm{C}$ which established that the metal-complexes were very stable. The review describes the promising biological activities of Schiff base and their metal complexes.
\end{abstract}

\section{Keywords}

Schiff Base Derivatives, Complexes, Thermodynamic Parameters, FTIR-Spectra, Mole Ratio Method, CHN Analysis, Biological Activity Studies

\section{Introduction}

Schiff base derived from an amine and carbonyl compound is an important class of ligands that coordinate to metal ions via azomethine nitrogen and has been studied extensively [1]. The characterization bond of Schiff base $(\mathrm{C}=\mathrm{N})$ has reversible nature which allows by hydrolysis, obtaining the initial corresponding aldehyde and amine compound [2] [3]. Schiff bases are known to be good chelating agents and easily prepared and characterized. Little interest has been given to their use for analytical purpose because of two serious drawbacks:

1) They are insoluble in aqueous solution. 
2) They decompose easily in acidic solution limiting their use to basic solution [4].

The chemistry of $(\mathrm{C}=\mathrm{N})$ double bond based complexes plays a vital role in the progress of chemistry and it has been found to possess the pharmacological activities such as malarial [5], anticancer [6], antibacterial [7]. Schiff base appears to be an important intermediate in a number of enzymatic reactions involving interaction of enzyme with an amino or carbonyl group of substitutes [8]. The aim of the study is the preparation of Schiff base derived from salicylaldehyde with a series of aniline derivatives. The structure of all Schiff bases was characterized by using FTIR spectra, CHN elemental analysis and UV-Visible. Their stability constant and their thermodynamic parameters such as $(\Delta \mathrm{E}, \Delta \mathrm{G}, \Delta \mathrm{H}$, and $\Delta \mathrm{S})$ were studied in different temperatures spectrophotometrically.

\section{Experimental}

\subsection{Material and Instrumentation}

All chemicals and solvents were purchased from Fluka and BDH chemical companies. Cobalt and copper acetate were dried over $\mathrm{P}_{4} \mathrm{O}_{10}$ under vacuum for several days before use. Melting point was recorded on VeeGO Digital model VMP-D. Jenway. Elemental analyses (CHN) were performed by Perkin Elemer TGA. IR spectra used in the characterization of products were recorded Shimadzu, FTIR-8400S-JAPAN. UV/Vis absorption studies were measured in the region (200 - 800) nm using $\left(10^{-4}\right) \mathrm{M}$ solution in ethanolic solution using U.V-9200 BIOTECH ENGINEERN MANAGEMENT CO. LTD (UK) Single beam.

\subsection{Preparation of Ligands}

The Schiff base was synthesized by refluxing ethanolic solution of (2.44 gm - $0.02 \mathrm{~mol}$ ) salicylaldehyde with (2.74 gm - $0.02 \mathrm{~mol}$ ) of substituted (o-benzoic, m-benzoic, p-benzoic) aniline in $20 \mathrm{ml}$ warm ethanolic solution $\left(40^{\circ} \mathrm{C}-50^{\circ} \mathrm{C}\right.$, to speed up the reaction), the ratio is (1:1) for two hours [9]. The ligand formed was filtered, washed, recrystallized from ethanol and then dried.

\subsection{Preparation of Schiff Base Metal Complexes}

An ethanolic solution of $\left(2 \times 10^{-2} \mathrm{M}\right)$ Schiff base was added to $\left(10^{-2} \mathrm{M}\right)$ of metal ions (as dehydrated acetate salts). The mixture was stirred and refluxed for two hours. The solid coloured product obtained was filtered, washed and recrystallized from ethanol and then dried.

\section{Result and Discussion}

\subsection{Physical Measurement}

Physical measurements of the synthesized ligand and their metal complexes and their expected formula are shown in Table 1. Melting point gives an impression that the synthesis from Schiff base and their complexes are without any contaminated material.

Table 1. Physical properties of synthesized ligand and their metal complexes.

\begin{tabular}{cccc}
\hline Compound & Colour & Yield & M.p. \\
\hline $\mathbf{L}_{1}$ & yellow & $78 \%$ & 120 \\
$\mathbf{C u}\left(\mathbf{L}_{1}\right)_{2}$ & sapphire & $56 \%$ & 187 \\
$\mathbf{C o}\left(\mathbf{L}_{1}\right)_{2}$ & mustard & $71 \%$ & 274 \\
$\mathbf{L}_{2}$ & Yellow-green & $82 \%$ & 141 \\
$\mathbf{C u}\left(\mathbf{L}_{2}\right)_{2}$ & Indigo & $69 \%$ & 263 \\
$\mathbf{C o}\left(\mathbf{L}_{2}\right)_{2}$ & Rose & $62 \%$ & 226 \\
$\mathbf{L}_{3}$ & Silver & $87 \%$ & 101 \\
$\mathbf{C u}\left(\mathbf{L}_{3}\right)_{2}$ & Azure & $63 \%$ & 190 \\
$\mathbf{C o}\left(\mathbf{L}_{3}\right)_{2}$ & Gray & $52 \%$ & 185 \\
\hline
\end{tabular}

$\mathrm{L}_{1}=\mathrm{o}$ - position, $\mathrm{L}_{2}=\mathrm{m}$ - position, $\mathrm{L}_{3}=\mathrm{p}$ - position. 


\subsection{The Elemental Analyses (CHN) of Ligand and Their Metal Complexes}

The data of element analysis (CHN) have shown that the results obtained are in good agreement with those calculated for suggested formula (Table 2).

\subsection{IR Spectrum of Ligand and Their Ligand Metal Complexes}

Table 3 shows the absence of band at $1735 \mathrm{~cm}^{-1}(\mathrm{C}=\mathrm{O})$ due to carbonyl and $3315 \mathrm{~cm}^{-1}$ for $\mathrm{NH}_{2}$ stretching vibration of strong new band appeared at $1630 \mathrm{~cm}^{-1}$ assigned to azomethine $(\mathrm{HC}=\mathrm{N})$ which indicates that amine and aldehyde of starting material are absent and have been converted into the new ligand. The IR spectra of complexes exhibited ligand bands with the appropriate Shifts due to complex formation $(\mathrm{C}=\mathrm{N})$ at $\left(1630 \mathrm{~cm}^{-1}\right)$ in free ligand shift to $\left(1620 \mathrm{~cm}^{-1}\right)$. The reduction in band order upon complexation can be attributed to delocalization of metal electron density to the $\pi$-system of the ligand. These Shifts confirm the coordination of the ligand via nitrogen of the azomethine to the metal ions (Figure 1). All lower frequency of complexes exhibited band around (400 - $600 \mathrm{~cm}^{-1}$ ) assigned to the $v(\mathrm{M}-\mathrm{N})[10][11]$.

\subsection{UV-Visible Spectrum of Ligand and Their Metal Complexes}

Spectrophotometrically from the wide studied range of molar concentration $\left(10^{-5}-10^{-3} \mathrm{M}\right)$ of the mixed solution only concentration of $\left(10^{-4} \mathrm{M}\right)$ obey Beer-lambert law and showed intense colour, A calibration curve was plotted on absorbance against molar concentration in the range of $\left(1 \times 10^{-4}-3 \times 10^{-4} \mathrm{M}\right)$, best fit straight line, were obtained. The composition of complexes formed in solution has been established by mole ratio and continuous variation methods, in both cases the result reveals (1:2) (M:L) ratio.

Table 2. Elemental analysis data for schiff bases and their complexes.

\begin{tabular}{cccc}
\hline \multirow{2}{*}{ Compound } & \multicolumn{3}{c}{ Founded ( calculated) } \\
\cline { 2 - 4 } $\mathbf{L}_{\mathbf{1}}$ & $\mathbf{\%}$ & $\mathbf{6 H}$ & $\mathbf{\%}$ \\
$\mathbf{C u}\left(\mathbf{L}_{1}\right)_{2}$ & $69.91(70)$ & $4.11(4.16)$ & $5.75(5.83)$ \\
$\mathbf{C o}\left(\mathbf{L}_{1}\right)_{2}$ & $62.24(62.27)$ & $2.82(2.96)$ & $5.09(5.18)$ \\
$\mathbf{L}_{2}$ & $62.90(62.81)$ & $3.05(2.99)$ & $5.14(5.23)$ \\
$\mathbf{C u}\left(\mathbf{L}_{2}\right)_{2}$ & $70.09(70)$ & $4.22(4.16)$ & $5.94(5.83)$ \\
$\mathbf{C o}\left(\mathbf{L}_{2}\right)_{2}$ & $62.26(62.27)$ & $2.93(2.96)$ & $5.25(5.18)$ \\
$\mathbf{L}_{3}$ & $62.89(62.81)$ & $2.89(2.99)$ & $5.18(5.23)$ \\
$\mathbf{C u}\left(\mathbf{L}_{3}\right)_{2}$ & $69.83(70)$ & $4.25(4.16)$ & $5.87(5.83)$ \\
$\mathbf{C o}\left(\mathbf{L}_{3}\right)_{2}$ & $62.22(62.27)$ & $2.85(2.96)$ & $5.12(5.18)$ \\
\hline
\end{tabular}

$\mathrm{L}_{1}=\mathrm{o}$ - position, $\mathrm{L} 2=\mathrm{m}$ - position, $\mathrm{L}_{3}=\mathrm{p}$ - position.

Table 3. IR spectra of Schiff base and its metal complexes.

\begin{tabular}{|c|c|c|c|c|c|c|c|}
\hline Compound & CH alphatic & CH aromatic & $\mathrm{C}=\mathrm{O}$ & $\mathbf{C}=\mathbf{N}$ & C-N & $\mathrm{C}=\mathrm{C}$ & $\mathbf{O H}$ \\
\hline $\mathbf{L}_{1}$ & 3400 & 3068 & - & 1616 & 1598 & 1425 & 1558 \\
\hline $\mathrm{Cu}\left(\mathrm{L}_{1}\right)_{2}$ & 3275 & 3115 & 2922 & 1598 & 1543 & 1357 & 1467 \\
\hline $\operatorname{Co}\left(L_{1}\right)_{2}$ & 3307 & - & - & 1597 & 1541 & 1300 & 1448 \\
\hline $\mathbf{L}_{2}$ & 3500 & 3055 & 2995 & 1622 & 1678 & 1365 & 1463 \\
\hline $\mathrm{Cu}\left(\mathrm{L}_{2}\right)_{2}$ & 3392 & 3066 & 2879 & 1614 & 1560 & 1305 & 1469 \\
\hline $\operatorname{Co}\left(L_{2}\right)_{2}$ & 3396 & 3070 & 2881 & 1614 & 1598 & 1390 & 1477 \\
\hline $\mathbf{L}_{3}$ & 3450 & 3074 & 2879 & 1680 & 1570 & 1431 & 1570 \\
\hline $\mathrm{Cu}\left(\mathrm{L}_{3}\right)_{2}$ & 3400 & 3018 & 2885 & 1614 & 1589 & 1398 & 1442 \\
\hline $\operatorname{Co}\left(L_{3}\right)_{2}$ & 3433 & - & 2881 & 1602 & 1556 & 1409 & 1436 \\
\hline
\end{tabular}

$\mathrm{L}_{1}=\mathrm{o}$ - position, $\mathrm{L}_{2}=\mathrm{m}$ - position, $\mathrm{L}_{3}=\mathrm{p}$ - position. 


\subsection{Determination the Stability Constant for Complexes}

$$
\alpha=\frac{A_{m}-A_{s}}{A_{m}}
$$

where $\alpha=$ degree of analysis [12] [13], $A_{m}=$ absorbance of equivalent amount of $L: M, A_{s}=$ absorbance of excess amount of ligand with constant volume of metal.

$$
K=\frac{1-\alpha}{4 \alpha^{3} C^{2}}
$$

where $C=$ concentration of the ligand which is equal the concentration of the metal.

\subsection{The Thermodynamic Parameters}

The thermodynamic parameters (Table 4) were calculated from their stability constant at different temperatures such as $(\Delta G, \Delta H$ and $\Delta S)$ from the following equation [14] [15]:

$$
\begin{gathered}
\Delta G=-R T \ln K \\
\ln \left(\frac{K_{2}}{K_{1}}\right)=\frac{\Delta H}{R}\left(\frac{1}{T_{2}}-\frac{1}{T_{1}}\right) \\
\Delta S=\frac{(\Delta H-\Delta G)}{T}
\end{gathered}
$$

where, $K=$ Stability Constant, $G=$ Free Energy, $H=$ Enthalpy, $S=$ Entropy.

\subsection{Biological Activity}

\begin{tabular}{|c|c|c|c|c|c|c|c|c|c|c|}
\hline \multirow{2}{*}{ Compound } & \multirow{2}{*}{$\lambda_{\max } \mathbf{n m}$} & \multicolumn{5}{|c|}{ at 303} & \multicolumn{4}{|c|}{ at 313} \\
\hline & & $\alpha$ & $K \times 10^{8}$ & $\Delta \boldsymbol{H}$ & $\Delta G$ & $\Delta S$ & $\alpha$ & K & $\Delta G$ & $\Delta S$ \\
\hline $\mathbf{L}_{1}$ & 396 & - & - & - & - & - & - & - & - & - \\
\hline $\mathrm{Cu}\left(\mathrm{L}_{1}\right)_{2}$ & 400 & 0.25 & 2.30 & 11.50 & 12.70 & -65 & 0.27 & 2.00 & 10.50 & -32 \\
\hline $\operatorname{Co}\left(L_{1}\right)_{2}$ & 412 & 0.29 & 1.90 & 13.70 & 11.40 & 12 & 0.30 & 1.80 & 9.70 & 25 \\
\hline $\mathbf{L}_{2}$ & 380 & - & - & - & - & - & - & - & - & - \\
\hline $\mathrm{Cu}\left(\mathrm{L}_{2}\right)_{2}$ & 391 & 0.31 & 1.70 & 10.90 & 12.90 & 24 & 0.33 & 1.50 & 8.70 & 13 \\
\hline $\operatorname{Co}\left(L_{2}\right)_{2}$ & 396 & 0.19 & 2.70 & 15.80 & 13.20 & 33 & 0.22 & 2.10 & 9.30 & -34 \\
\hline $\mathbf{L}_{3}$ & 400 & - & - & - & - & - & - & - & - & - \\
\hline $\mathrm{Cu}\left(\mathbf{L}_{3}\right)_{2}$ & 408 & 0.22 & 2.60 & 11.00 & 14.90 & 53 & 0.25 & 2.30 & 11.30 & 41 \\
\hline $\operatorname{Co}\left(L_{3}\right)_{2}$ & 415 & 0.31 & 1.70 & 13.80 & 12.30 & -41 & 0.32 & 1.60 & 9.80 & 30 \\
\hline
\end{tabular}

The biological activity were studied, the effect of schiff base derivatives and its complexes on two type of

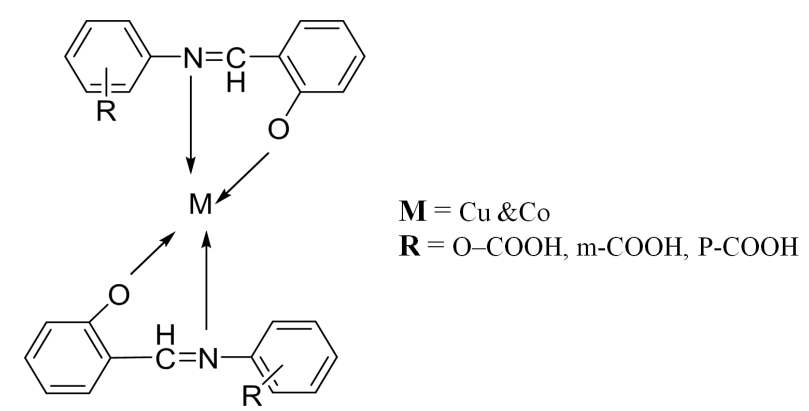

Figure 1. Suggest structure of metal—complexes Schiff base.

Table 4. Shows the difference stability at different temperature and then thermodynamic parameter was recorded. 
Table 5. The biological activity of ligand and their metal complexes.

\begin{tabular}{ccc}
\hline Compound & Aeromomas hydrophila $(-)$ & Staphylococcus aureus $(+)$ \\
\hline $\mathbf{L}_{1}$ & - & - \\
$\mathbf{C u}\left(\mathbf{L}_{1}\right)_{2}$ & - & 12 \\
$\mathbf{C o}\left(\mathbf{L}_{1}\right)_{2}$ & - & 10 \\
$\mathbf{L}_{2}$ & - & 10 \\
$\mathbf{C u}\left(\mathbf{L}_{2}\right)_{2}$ & - & 12 \\
$\mathbf{C o}\left(\mathbf{L}_{2}\right)_{2}$ & - & 10 \\
$\mathbf{L}_{3}$ & - & 10 \\
$\mathbf{C u}\left(\mathbf{L}_{3}\right)_{2}$ & - & 12 \\
$\mathbf{C o}\left(\mathbf{L}_{3}\right)_{2}$ & - & 10 \\
\hline
\end{tabular}

$\mathrm{L}_{1}=\mathrm{o}$ - position, $\mathrm{L}_{2}=\mathrm{m}$ - position, $\mathrm{L}_{3}=\mathrm{p}$ - position.

Bacteria Aeromomas hydrophila (-) and Staphylococcus aureus (+) have been described in Table 5. The result show that the complexes have more toxicity against the bacterial species than free ligand. This can be attributed to the tweeds chelation theory [16] according to which the chelation reduces the polarity of metal ions mainly because of the partial sharing of its positive charge with donor group and possible electro delocalization over the whole ring.

\section{Conclusion}

Schiff base of [o-benzyl, m-benzyl, p-benzyl] aniline with salisaladehyed was synthesized and characterized by analytical and spectral, FTIR, CHN technique. These compounds exhibited significant biological activities.

\section{Acknowledgements}

The author thanks the Iraqi Government, Ministry of Higher Education and Basrah University for the financial support provided for this work. The author is thankful of the support of the college of Education and Iraq Marine Science Center, Basrah University in undertaking the antibacterial studies.

\section{References}

[1] Montazerozohori, M., Sedighipoor, M. and Joohari, S. (2012) Electrochemical Behavior of Bis((E) 3-(2-nitrophenyl) allylidene)propane-1,2-diamine as a New Schiff Base and Some Its New XII Group Complexes. International Journal of Electrochemistry, 7, 77- 88.

[2] Shabani, F. and Ghammamy, S. (2009) Synthesis, Characterization and Anti-Tumour Activity of VOF 3 and Cu (II) Porphyrine Complexes. Der Pharma Chemica, 1, 124-125.

[3] Kim, J.H., Kim, H.J., Bae, C.W., Park, J.W., Lee, J.H. and Kim, J.S. (2010) $\mathrm{Hg}^{2+}$-Induced Hydrolysis-Based Selective Fluorescent Chemodosimeter. ARKIVOC, 7, 170-178.

[4] Ashraf, M.Q., Mahmood, K. and Wajid, A. (2011) International Conference on Chemistry and Chemical Process, 10, $1-7$.

[5] Saberyan, K., Shamsipur, M., Zolfonoun, E. and Niasari, M.S. (2008) Liquid-Liquid Distribution of the Tetravalent Zirconium, Hafnium and Thorium with a New Tetradentate Naphthol-Derivative Schiff Base. Bulletin of the Korean Chemical Society, 29, 94-98. http://dx.doi.org/10.5012/bkcs.2008.29.1.094

[6] Mishra, K., Power, A., Chopra, P., Sharma, M. and Chatal, R. (2003) Synthesis of Novel Bifunctional Schiff-Base Ligands Derived from Condensation of 1-(p-Nitrobenzyl)ethylenediamine and 2-(p-Nitrobenzyl)-3-monooxo-1,4,7triazaheptane with Salicylaldehyde. New Journal of Chemistry, 27, 1054-1058. http://dx.doi.org/10.1039/B300621M

[7] Zhang, Y., Wang, X.M. and Ding, L.S. (2010) Interaction between Tryptophan-Vanillin Schiff Base and Herring Sperm DNA. Journal of the Serbian Chemical Society, 75, 1191-1201. http://dx.doi.org/10.2298/JSC100128107Z

[8] Rizwana, B. and Lakshmi, S.S. (2012) Synthesis, Characterisation and Antimicrobial Studies of Zn(II), Ni(II) and $\mathrm{Cu}(\mathrm{II})$ Complexes of a Schiff Base Derived from o-Vanillin and N-Allyl Thiourea. International Journal of ChemTech Research, 4, 464-473.

[9] Nejo, A.A. (2009) Ph. D Thesis, University of Zululand, Mhlathuze. 
[10] Mukherjee, P., Sengupta, O., Drew, M.G.B. and Ghosh, A. (2009) Anion Directed Template Synthesis of Cu(II) Complexes of a N,N,O Donor Mono-Condensed Schiff Base Ligand: A Molecular Scaffold Forming Highly Ordered H-Bonded Rectangular Grids. Inorganica Chimica Acta, 362, 3285-3291. http://dx.doi.org/10.1016/j.ica.2009.02.041

[11] Moor, W.J. (1972) Physical Chemistry. 5th Edition, Longrman SROUP Ltd., London, 32.

[12] Lancashine, R.J. (2005) Stability, Chelation and the Chelation and Effect. Lecture 5. CHEM1902 Coordination Chemistry. 1-5.

[13] Zhang, Y., Xiang, L., Wang, Q., Duan, X.F. and Zi, G.Z. (2008) Synthesis, Structure, and Catalytic Activity of Chiral $\mathrm{Cu}(\mathrm{II})$ and $\mathrm{Ag}(\mathrm{I})$ Complexes with (S,S)-1,2-Diaminocyclohexane-Based $\mathrm{N}_{4}$-Donor Ligands. Inorganica Chimica Acta, 361, 1246-1254. http://dx.doi.org/10.1016/j.ica.2007.08.003

[14] Bjerrum, I.J. (1952) Metal Amine Formation Aqueous Solution. John Wiley, Inc., Hoboken.

[15] Bdeiwe, S.F. (2002) Determination of Stability Constant and Thermodynamic Parameters for Some Schiff Base Complexes with Silver Chloride. Ph.D. Thesis, Mosul University, Mosul.

[16] Cordova, A. (2004) The Direct Catalytic Asymmetric Mannich Reaction. Accounts of Chemical Research, 37, $102-112$. http://dx.doi.org/10.1021/ar0302311 